\title{
Capsule endoscopy assisted by traditional upper endoscopy
}

\author{
N. Almeida, P. Figueiredo, S. Lopes, P. Freire, C. Lérias, Hermano Gouveia and M. Correia Leitão \\ Department of Gastroenterology. Coimbra University Hospital. Portugal
}

\section{RESUMEN}

Antecedentes y objetivos: la cápsula endoscópica puede resultar inútil en caso de dificultad para tragar el dispositivo y/o de retención gástrica del mismo. En tales casos, llevar la cápsula hasta el duodeno mediante endoscopia resulta muy útil.

Describimos las indicaciones y los resultados de unos casos en que las técnicas endoscópicas tradicionales permitieron llevar la cápsula hasta el duodeno.

Pacientes y métodos: se trata de una serie descriptiva y retrospectiva de casos. Se identificaron todos los pacientes en las situaciones citadas y se anotaron las indicaciones de la cápsula endoscópica, la técnica endoscópica de colocación, las complicaciones y el grado de cobertura del intestino delgado por las imágenes.

Resultados: la colocación endoscópica de la cápsula se hizo necesaria en 13 pacientes ( $2,1 \%$ de todas las endoscopias con cápsula; 7 varones; media de edad - 47,9 $\pm 24,9$ años, intervalo de 13 a 79 años). Las indicaciones de la colocación endoscópica fueron: incapacidad para tragar la cápsula (7), retención gástrica en exploraciones previas (3) y anomalías de la anatomía digestiva alta (3). En ocho casos, la cápsula se introdujo en la vía GI mediante: sólo la red para recuperar cuerpos extraños (3), la red y un capuchón transparente (2), el prototipo de un dispositivo a tal efecto (2) o una asa de polipectomía (1). Cinco pacientes ingirieron la cápsula, llevada después al duodeno con una asa de polipectomía (3) o una red para cuerpos extraños (2). No se produjeron complicaciones de importancia. La enteroscopia total fue posible en 10 pacientes (77\%).

Conclusiones: la colocación endoscópica de la cápsula en el duodeno sólo es necesaria rara vez, puede realizarse de forma segura con distintas técnicas y soluciona algunas de las principales limitaciones de la cápsula endoscópica. Las mejores metodologías son la utilización de una red y un capuchón transparente cuando el paciente no pudo ingerir la cápsula y sólo una red para capturarla en el estómago si la traga fácilmente.

Palabras clave: Cápsula endoscópica. Endoscopia digestiva alta. Trastornos de la deglución. Gastroparesia.

\begin{abstract}
Background and aims: capsule endoscopy (CE) can be prevented by difficulties in swallowing the device and/or its gastric retention. In such cases, endoscopic delivery of the capsule to duodenum is very useful.

We describe the indications and outcomes of cases in which traditional endoscopic techniques allowed placement of the capsule in duodenum.

Patients and methods: this is a retrospective, descriptive case series. All patients in the above conditions were identified and indications for $\mathrm{CE}$, endoscopic-placement technique, complications and completeness of small bowel imaging were registered.

Results: endoscopic-assisted delivery of the capsule was necessary in 13 patients (2.1\% of all CE; 7 males; mean age $-47.9 \pm$ 24.9 years, range 13 to 79 years). Indications for endoscopic delivery included: inability to swallow the capsule (7), gastric retention in previous exams (3), abnormal upper gastrointestinal anatomy (3). In eight patients, the capsule was introduced in GI tract with: foreign body retrieval net alone (3), retrieval net and a translucent cap (2), prototype delivery device (2) or a polypectomy snare (1). Five patients ingested the capsule that was then placed in duodenum with a polypectomy snare (3) or a retrieval net (2). No major complications occurred. Complete small bowel examination was possible in 10 patients (77\%).

Conclusions: endoscopic placement of capsule endoscope in the duodenum is rarely needed. However it may be safely performed by different techniques avoiding some limitations of $\mathrm{CE}$. The best methods for endoscopic delivery of the capsule in the duodenum seem to be a retrieval net with a translucent cap when the patient is unable to swallow the device or a retrieval net only to capture the capsule in the stomach when the patient swallows it easily.
\end{abstract}

Key words: Capsule endoscopy. Upper gastrointestinal endoscopy. Swallowing disorders. Gastroparesis.

Almeida N, Figueiredo P, Lopes S, Freire P, Lérias C, Hermano Gouveia, Correia Leitão M. Capsule endoscopy assisted by traditional upper endoscopy. Rev Esp Enferm Dig 2008; 100: 758-763.

Recibido: 17-08-08

Aceptado: 10-10-08.

Correspondencia: Nuno Almeida. Department of Gastroenterology. Coimbra University Hospital. Praceta Mota Pinto and Av. Bissaya Barreto. 3000-075 Coimbra, Portugal. e-mail: nunoperesalmeida@gmail.com 


\section{BACKGROUND AND AIMS}

Since its first published presentation in 2000 (1), capsule endoscopy (CE) revolutionized our approach to small bowel pathologies. CE is now a first-line diagnostic tool in obscure gastrointestinal bleeding (OGIB), suspected Crohn's disease, suspected small bowel tumours, and other abnormalities of the small bowel (2-7). Although it is a relatively safe and well tolerated procedure, $\mathrm{CE}$ has some contraindications: known or suspected gastrointestinal obstruction, stricture, fistula or extensive Crohn's disease; swallowing disorders; upper GI abnormalities (esophageal diverticula including Zenker's, large hiatal hernia); pregnancy (6-9).

The capsule measures $26 \times 11 \mathrm{~mm}$ and not all patients can swallow it easily. Inability to swallow the capsule and ineffective swallowing may be a major problem in some patient groups requiring CE: the elderly, the pediatric population, patients with oropharyngeal diseases or upper GI abnormalities, sedated patients. On the other side, gastric retention of CE may occur in some patients due to functional (i.e. gastroparesis) or anatomical (i.e. pyloric stenosis) abnormalities. Fortunately, these problems, that may potentially prevent small bowel examination by $\mathrm{CE}$, are rare. Rondonotti et al. (8), reported in a large series of CE examinations that difficulty/inability to swallow the capsule occurred in $1.5 \%$ of patients and gastric retention in $2.34 \%$.

Both problems can be solved using traditional upper endoscopy to deliver the capsule directly in the duodenum. Many different techniques have been described (1015), even for the pediatric population (16-18). All techniques are apparently successful. Our aim was hereby to describe our experience with such procedures and the reasons for their utilization.

\section{PATIENTS AND METHODS}

This is a retrospective, case series, descriptive study. All 620 CE studies performed between July 2001 and January 2008 were reviewed and the cases where upper traditional endoscopy was performed to deliver the capsule endoscope in the duodenum identified. Age, sex, reason for $\mathrm{CE}$, indication for $\mathrm{CE}$ endoscopic delivery, method used, complications and rate of complete enteroscopy were registered. All patients or their legal representatives gave informed consent for $\mathrm{CE}$ and upper endoscopy. All CE examinations were performed with the PillCam SB (Given Imaging, Yoqneam, Israel) and upper endoscopies with a standard diagnostic endoscope from Olympus.

Patients were divided in two groups: those who swallowed the capsule that was subsequently captured in the stomach (group 1); those who did not swallow the capsule endoscope (group 2). Endoscopy was performed under sedation in two patients (the younger ones). One pa- tient had endotracheal protection of the airways. All patients received a prokinetic (metoclopramide, $10 \mathrm{mg}$ IV or per os) immediately before or after CE delivery to duodenum. The method for endoscopic delivery of the capsule was chosen according to the gastroenterologist's previous experience and expertise.

\section{RESULTS}

Endoscopic-assisted delivery of CE into the duodenum was necessary in $13 \mathrm{CE}$ examinations $(2.1 \%)$, corresponding to 13 patients ( 7 males, 6 females; mean age $47.9 \pm 24.9$ years, range $13-79)$. Evaluation for obscure gastrointestinal bleeding was the main indication $(n=7)$. Six patients had overt bleeding and one had iron-deficiency anemia. In five patients, there was a suspicion of Crohn's disease. A small bowel tumour was suspected in one patient. All them had already undergone upper and lower diagnostic endoscopies before $\mathrm{CE}$.

Seven of the 13 patients $(53.8 \%)$ were unable to swallow the capsule. The inability to swallow the device was detected at the beginning of CE in six patients. In the seventh patient, a boy of 13 years, predicting such problem, we performed a trial with a candy similar to the capsule. Since the boy was not able to swallow the candy, we decided to deliver the capsule in the duodenum by traditional upper endoscopy under general anesthesia.

Three patients $(23.1 \%)$ had upper GI abnormality (pyloric stenosis in two and antrum-pyloric deformation in one) that could potentially prevent capsule passage into the duodenum. The last three patients $(23.1 \%)$ had previous unsuccessful CE studies because of capsule's gastric retention.

Direct endoscopic placement of the capsule in duodenum took place in the 7 patients unable to swallow the capsule and in one of the other 6 patients because an experimental delivery device was used in this case.

Five patients swallowed the capsule (Group 1) that was easily grasped in the stomach (Fig. 1) with a polypectomy snare (Snaremaster SD-210U-25, Olympus) $(n=3)$ or a foreign body retrieval device (Roth net, US Endoscopy, Mentor, Ohio) $(n=2)$. In eight patients (Group 2) the capsule was preloaded in the endoscope with different devices: a foreign body retrieval net alone $(\mathrm{n}=3)$; a retrieval net and a translucent cap (MH-463, Olympus optical, Lisbon, Portugal) $(\mathrm{n}=2)$; an experimental device $(\mathrm{n}=2)$; a polypectomy snare (Snaremaster SD-210U-25, Olympus optical, Lisbon, Portugal) $(n=1)$.

The foreign body retrieval net used in 2 patients in Group 1 and 5 patients in Group 2, had a loop diameter of $25 \mathrm{~mm}$ and was initially sprinkled with a lubricant spray (Rusch Silkospray, Willy-Rusch AG, Kemen, Germany) to avoid difficulties in releasing the capsule. The activated capsule was then placed in the basket and the loop was closed, pulling the capsule snug against the tip of the endoscope (Fig. 2). In Group 2, the retrieval net was used 


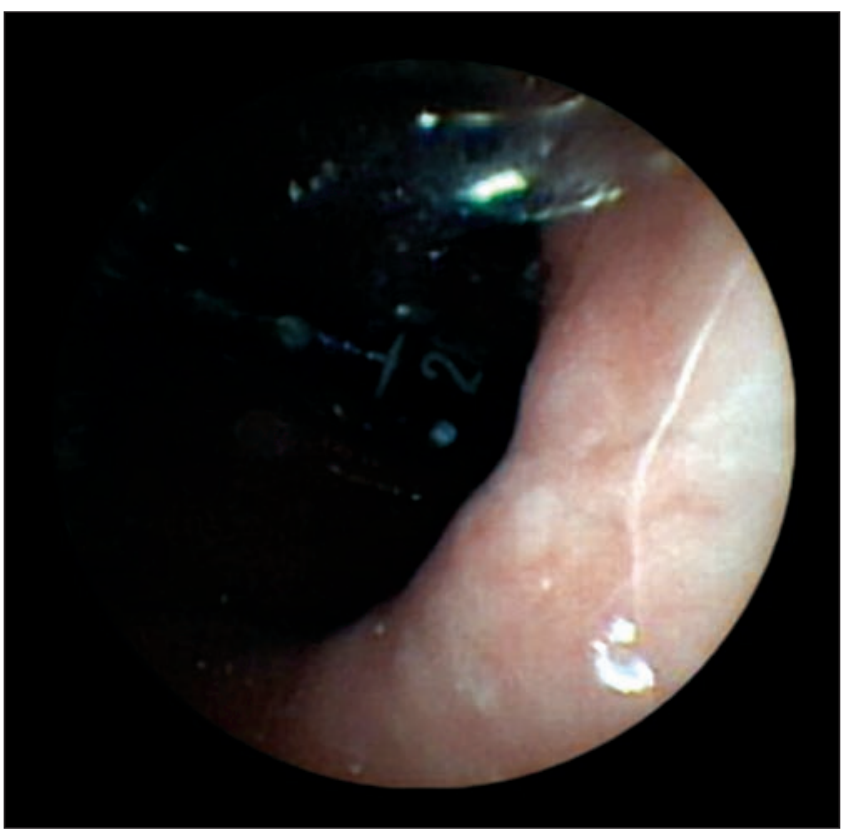

Fig. 1. Image of the upper endoscope captured by the capsule that was already in the stomach.

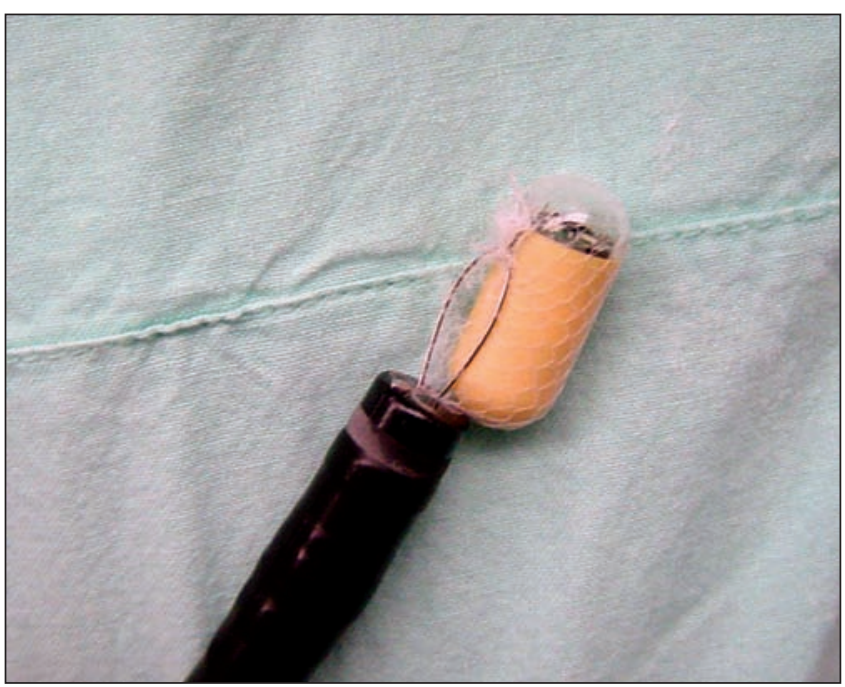

Fig. 2. Activated capsule endoscope in the net retrieval catheter passed through the gastroscope.

alone in three patients but in another two a translucent cap was attached to the tip of the endoscope and the capsule was placed in the net, which was then closed and pulled back toward the endoscope, stabilizing the capsule inside the cap (Fig. 3). In either case, the capsule was easily released in duodenum (Fig. 4). A prototype of a delivery device was used in two patients. This device had a small cup in the distal extremity and a long tube passed through the channel of the endoscope. The distal cup remained attached to the tip of the endoscope and the activated capsule was placed in this cup. With the help of a syringe attached to the proximal end of the device, vacu-

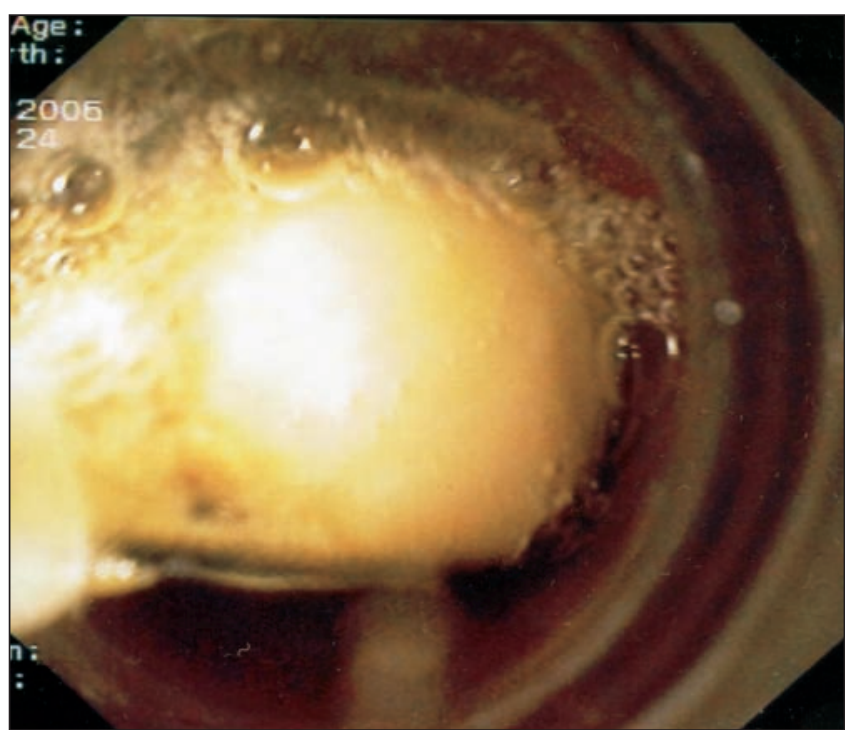

Fig. 3. Capsule endoscope stabilized with the retrieval net and a translucent cap attached to the distal end of the gastroscope.

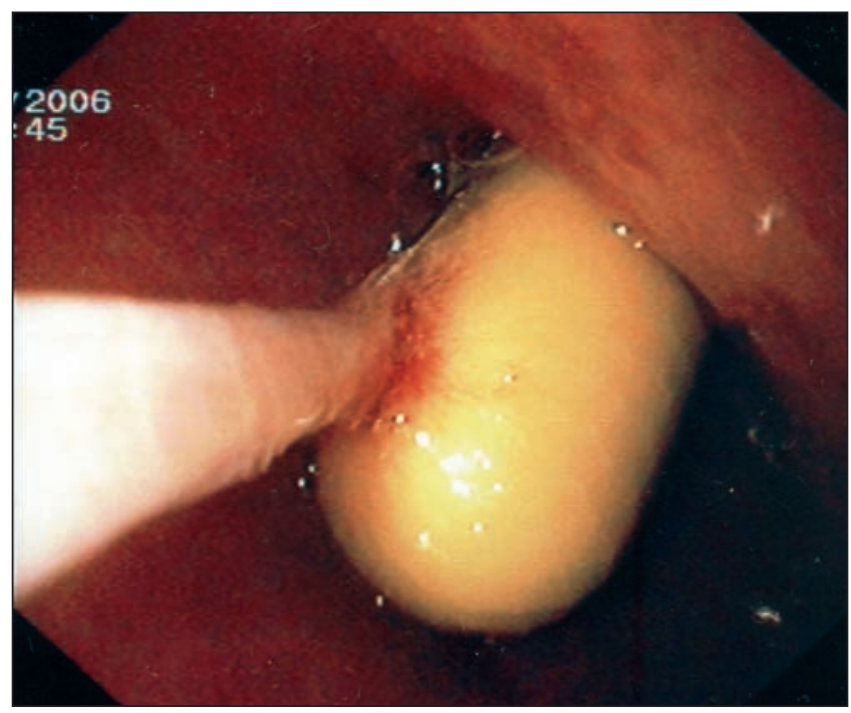

Fig. 4. Capsule endoscope secured in the retrieval net while passing duodenal bulb.

um was created and the capsule was held in position by this procedure. When duodenum was reached, the vacuum was stopped and the capsule released. Finally, in one patient, the capsule was introduced using a polypectomy snare. This patient had 13 years and was the only one with endotracheal intubation.

With these methods, the capsule was successfully delivered to duodenum in all patients. In those that swallowed the capsule there were no major difficulties to capture and pass it into the duodenum but this procedure was easier with the retrieval net comparatively to the polypectomy snare. In the eight patients that did not swallow the capsule, four different procedures were used. With the foreign body retrieval net alone there were some difficul- 
ties in one patient to control the capsule while advancing through the pharynx and upper esophageal sphincter. With the translucent cap and the experimental delivery device there were no difficulties in GI intubation but visualization was better with the cap. In all cases in which the net was used there were no difficulties to release the capsule in the duodenum. In the only case in which the polypectomy snare was used the capsule dislodged in the pharynx but, as the patient had endotracheal intubation, no airway complications occurred and the capsule was easily recovered with the snare and placed in duodenum. This was the worst complication of all procedures. Minor duodenal mucosal abrasions and bleeding occurred in some patients but had no interference in CE.

Total small bowel examination was possible in 10 patients $(77 \%)$. Capsule retention occurred in a girl of 13 years, with major growth retardation. She was submitted to surgery and Crohn's disease was the final diagnosis.

The characteristics of all 13 patients are resumed in table I and figure 5.

\section{DISCUSSION}

Capsule endoscopy has today an indisputable leading role in small bowel imaging. $\mathrm{CE}$ is relatively easy for gastroenterologists to perform and a growing number of patients are submitted to this examination. It is not surprising that the limitations of this endoscopic technique are becoming more important in the clinical setting (19). Inability to swallow the capsule and/or gastric retention are major limitations and hinder $\mathrm{CE}$ in such circumstances. Fortunately, these limitations are rare (8), and can be surpassed with traditional upper endoscopy supporting. Multiple different techniques have been already described to deliver the device in the duodenum (10-15). The procedure is easy if the patient is able to swallow the capsule because it is only necessary to capture it in the stomach and pass it through the pylorus. In patients unable to swallow the capsule or with esophageal/gastric abnormalities preventing capsule transit, traditional upper endoscopy or even an overtube may be necessary.

Table I. Characteristics of the 13 patients who underwent endoscopic delivery of CE

\begin{tabular}{|c|c|c|c|c|c|c|c|}
\hline Patient & Age, year & Sex & CE indication & $\begin{array}{l}\text { Indication for endoscopic } \\
\text { delivery }\end{array}$ & $\begin{array}{l}\text { Capsule } \\
\text { swallowed }\end{array}$ & Technique & $\begin{array}{l}\text { Total small } \\
\text { bowel exam }\end{array}$ \\
\hline 1 & 23 & $M$ & Suspected CD & Pyloric stenosis & Yes & PS & Yes \\
\hline 2 & 38 & M & Suspected CD & Gastric retention & Yes & PS & Yes \\
\hline 3 & 66 & M & OGIB & Swallowing incapacity & No & PD & Yes \\
\hline 4 & 60 & $\mathrm{~F}$ & $O G I B$ & Gastric retention & Yes & PS & No \\
\hline 5 & 50 & $\mathrm{~F}$ & $O G I B$ & Gastric retention & No & $P D$ & Yes \\
\hline 6 & 79 & $\mathrm{~F}$ & OGIB & Swallowing incapacity & No & RN + Cap & Yes \\
\hline 7 & 34 & $\mathrm{~F}$ & Suspected CD & Pyloric stenosis & Yes & RN & Yes \\
\hline 8 & 74 & M & OGIB & Antrum-pyloric deformation & Yes & RN & Yes \\
\hline 9 & 24 & $\mathrm{~F}$ & Suspected CD & Swallowing incapacity & No & RN & Yes \\
\hline 10 & 13 & $\mathrm{M}$ & Suspected CD & Swallowing incapacity & No & PS & No \\
\hline 11 & 13 & $\mathrm{~F}$ & Suspected SB tumour & Swallowing incapacity & No & RN & No; retention \\
\hline 12 & 75 & M & OGIB & Swallowing incapacity & No & RN & Yes \\
\hline 13 & 73 & M & OGIB & Swallowing incapacity & No & RN + Cap & Yes \\
\hline
\end{tabular}

CD: Crohn's disease; OGIB: obscure gastrointestinal bleeding; PS: polypectomy snare; PD: prototypical device; RN: retrieval net; SB: small bowel.

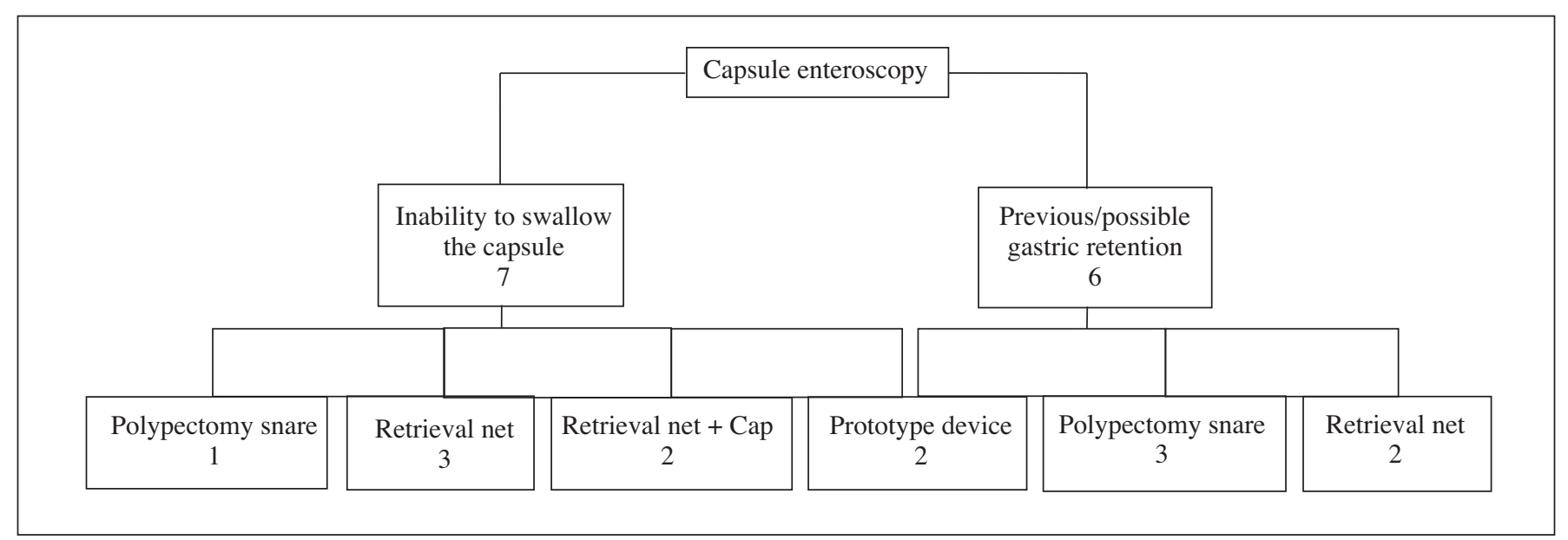

Fig. 5. Characteristics of the 13 patients who underwent endoscopic delivery of CE. 
In our series, direct placement of $\mathrm{CE}$ in the duodenum occurred in only one of six patients capable of capsule ingestion because an experimental device was used in that specific case. This device must be attached to the gastroscope already with the activated capsule and is impossible to capture a capsule in the stomach with such instrument. All the remaining five patients swallowed easily the capsule.

To grasp the capsule in the stomach a foreign body retrieval net or a polypectomy snare can be used. In our limited experience, the use of the retrieval net was easier because the capsule surface is smooth and slips easily from the polypectomy snare. On the other side, axis alignment between the capsule and the endoscope while passing the pylorus is easier to maintain with the net.

With one exception, all patients unable to swallow the capsule belong to one of two groups: elderly or children. Minimal age limit for admission in our hospital is 13 years-old so we rarely perform $\mathrm{CE}$ in children under this age. The two reported in this paper were the youngest of all our capsule examinations series. Both had growth retardation and were considerably smaller for their age. General anesthesia was necessary in both, with endotracheal airway protection in one. General anesthesia should not be required for endoscopic placement of a capsule endoscope in all cases (16), but probably it is inevitable in children because of their anatomic particularities (smaller, more compressible airways) and potential longer examinations (difficulties passing the upper esophageal sphincter and the pylorus).

During the seven years of CE in our institution, we had to introduce the capsule endoscope in the gastrointestinal tract with conventional upper endoscopy in eight patients. We used four different techniques including a prototype system in certain way similar to the AdvanCE delivery system (US Endoscopy, Mentor, Ohio), at least concerning position in front of the gastroscope. Of all four different methods the easier and safest one was the combination of the retrieval net with a translucent cap because the capsule was perfectly stabilized, aligned linearly with the gastroscope, and it was possible to obtain a partial visualization of anatomic structures and mucosal detail. The degree of visualization and capsule control was larger than with the experimental delivery device. The worst method is the simple use of a polypectomy snare because the capsule easily slips from the snare in the pharynx and airway aspiration is a real risk. We only tried this procedure in a patient with airway protection but we strongly disadvise its utilization.

One of the problems with the retrieval net seems to be the release of the capsule because the net tends to become saturated with duodenal secretions, sticking the capsule to the mesh. Carey et al. (10) even had to use Argon Plasma coagulation to release the capsule in one patient. Bizzarri et al. (17) opted to break some of the net's mesh easing the release of the capsule by strongly closing the net, forcing the breakage of all mesh. Our experience with the lubricant spray was very good since we had no problems with capsule release in duodenum. Another problem of the net is the possibility of minor abrasions and bleeding from the mucosa but this is generally very limited and does not interfere with capsule enteroscopy.

Some authors described the utilization of an overtube to introduce the capsule in GI tract (12-14). We had experience with overtubes for removing foreign bodies from GI tract but the high rate of complications from their use is well established $(20,21)$. Like Holden et al (11), we think that using an overtube to introduce CE in the stomach does not seem a good option since there are other safer methods that allow placement of the capsule directly in duodenum. The only advantage of the overtube would be the protection of the airways without the need for endotracheal intubation.

It is worth noting that we had no cases of previous gastro-duodenal diversion surgical procedures in our series. Until now we had no problems with such patients and no endoscopic accessory technique was necessary.

In summary, we found that endoscopic placement of PillCam SB (Given Imaging, Yoqneam, Israel) is possible in patients for whom CE examination would be contraindicated or impracticable because of their inability to swallow the capsule endoscope or the presence of upper GI anatomic or motility abnormalities preventing adequate capsule transit. The best method seems to be the concomitant use of a foreign body retrieval net and a translucent cap when the patient is unable to swallow the capsule. When swallowing of the device is possible, the simple use of the retrieval net alone is sufficient to deliver the capsule to duodenum. In both circumstances, lubrication of the net with a spray eases capsule release.

\section{REFERENCES}

1. Iddan G, Meron G, Glukhovsky A, Swain P. Wireless capsule endoscopy. Nature 2000; 405: 417.

2. American Society for Gastrointestinal Endoscopy. ASGE technology status evaluation report: wireless capsule endoscopy. Gastrointest Endosc 2006; 63: 539-45.

3. Mergener K, Ponchon T, Granek I, Pennazio M, Gay C, Selby W, et al. Consensus statements for small-bowel capsule endoscopy, 2006/2007. Endoscopy 2007; 39: 895-909.

4. Pennazio M. Capsule endoscopy: Where are we after 6 years of clinical use? Digest Liver Dis 2006; 38: 867-78.

5. Rondonotti E, Villa F, Mulder CJ, Jacobs M, De Franchis R. Small bowel capsule endoscopy in 2007: Indications, risks and limitations. World J Gastroenterol 2007; 13: 6140-9.

6. Rey JF, Ladas S, Alhassani A, Kuznetsov K and the ASGE Guidelines Committee. Video capsule endoscopy: Update to guidelines (May 2006). Endoscopy 2006; 38: 1047-53.

7. Matas JL, Asteinza M, Loscos JM, Fernández S, Ramírez-Armengol JA, Díaz-Rubio M. Diagnostic yield and safety of capsule endoscopy. Rev Esp Enferm Dig 2006; 98: 666-73.

8. Rondonotti E, Herrerias JM, Pennazio M, Caunedo A, MascarenhasSaraiva M, De Franchis R. Complications, limitations, and failures of capsule endoscopy: a review of 733 cases. Gastrointest Endosc 2005; 62: 712-6.

9. Barkin JS, Loughlin C. Capsule endoscopy contraindications: complications and how to avoid their occurrence. Gastrointest Endosc 
Clin N Am 2004; 14: 61-5.

10. Carey EJ, Heigh RI, Fleisher DE. Endoscopic capsule endoscope delivery for patients with dysphagia, anatomical abnormalities, or gastroparesis. Gastrointest Endosc 2004; 59: 423-6.

11. Holden JP, Dureja P, Pfau PR, Schwartz DC, Reichelderfer M, Judd $\mathrm{RH}$, et al. Endoscopic placement of the small-bowel video capsule by using a capsule endoscope delivery device. Gastrointest Endosc 2007; 65: 842-7.

12. Quan C, Ghen G, Lee-Henderson M, Kalpakian M, Chan S, Tran T, et al. Overtube-assisted placement of the wireless capsule endoscopy device. Gastrointest Endosc 2005; 61: 14-6.

13. Toth E, Fork T, Almqvist P, et al. Endoscopically-assisted capsule endoscopy in patients with swallowing disorders. Endoscopy 2004; 36: 745 .

14. Skogestad J, Tholfsen J. Capsule endoscopy: in difficult cases capsule can be ingested through an overtube. Endoscopy 2004;36:1038

15. Hollerbach S, Kraus K, Willert J, Schulmann K, Schmeigel W. Endoscopically assisted video capsule endoscopy of the small bowel in patients with functional gastric outlet obstruction. Endoscopy 2003; 35: 226-9.

16. Barth BA, Donovan K, Fox VL. Endoscopic placement of the capsule endoscope in children. Gastrointest Endosc 2004; 60: 818-21.

17. Bizzarri B, Fornaroli F, Cannizzaro R, de'Angelis N, Vincenzi F, Maffini V, de'Angelis GL. Endoscopic placement of video capsule in a pediatric population. Gastrointest Endosc 2005; 62: 991.

18. Aabaken L, Scholz T, Ostensen AB, Emblem R, Jermstad T. Capsule endoscopy is feasible in small children. Endoscopy 2003; 35: 798

19. Hollerbach $\mathrm{S}$, Wiedbrauck F. How to slip the capsule down a narrow throat: Reply to Tóth et al. Endoscopy 2004; 36: 747-8.

20. Dennert B, Ramirez FC, Sanowski RA. A prospective evaluation of the endoscopic spectrum of overtube-related esophageal mucosal injury Gastrointest Endosc 1997; 45: 134-7.

21. Carr-Locke DL, Al-Kawas FH, Branch MS, Byrne WJ, Edmundowicz SA, Jamindar PA, et al. Overtube use in gastrointestinal endoscopy. Gastrointest Endosc 1996; 44: 767-70. 